\title{
Urinary incontinence and perineal muscle function in physically active and sedentary elderly women
}

\author{
Incontinência urinária e função muscular perineal em idosas \\ praticantes e não-praticantes de atividade física regular
}

Janeisa F. Virtuoso', Giovana Z. Mazo², Enaiane C. Menezes ${ }^{3}$

\begin{abstract}
Objective: To identify the presence of urinary incontinence and compare perineal muscle function among physically active and sedentary older women. Methods: The sample consisted of 39 elderly women, 28 of whom got regular physical activity (AG) and 11 did not (SG). We collected data on risk factors for pelvic floor weakness and the presence of urinary incontinence (UI). The evaluation of perineal function was performed using PERFECT and perineometry. The data were processed with descriptive (simple frequencies, percentages, measures of position and dispersion) and inferential statistics (Chi-square or Fisher Exact Test, when necessary, and Mann-Whitney) with a significance level of $5 \%$. Results: There was a higher mean age ( $p=0.04)$ in AG. The occurrence of UI in the sample was $56.4 \%$. Urge UI was associated with $S G(p=0.022)$. All PERFECT variables were higher in $A G$ than $S G$, with significant differences for the variables "repetitions" ( $p=0.008)$ and "fast" $(p=0.022)$. Perineometry revealed that fast twitch fibers $(p=0.008)$ and slow twitch fibers $(p=0.05)$ were higher in the AG. Conclusion: $A G$ had better pelvic floor muscle function. However, the prevalence of $\mathrm{UI}$ was higher in this group, which suggested the influence of age on the urinary continence mechanism.
\end{abstract}

Keywords: pelvic floor; perineum; muscle strength; urinary incontinence; physical activity; elderly.

\section{Resumo}

Objetivo: Identificar a presença de incontinência urinária (IU) e comparar a função muscular perineal entre idosas praticantes e nãopraticantes de atividade física regular. Métodos: Participaram deste estudo 39 idosas, sendo 28 praticantes (GP) e 11 não-praticantes de atividade física regular (GNP). Foram coletados dados referentes aos fatores de risco para enfraquecimento do assoalho pélvico e presença de IU. A avaliação da função perineal foi feita por meio do esquema PERFECT e da perineometria. Utilizou-se estatística descritiva (frequência simples, porcentagem, medidas de posição e dispersão) e inferencial (teste do qui-quadrado ou Exato de Fisher, quando necessário, e teste de Mann-Whitney). O nível de significância adotado foi de $5 \%$. Resultados: A variável idade $(p=0,04)$ apresentou média superior no GP. A ocorrência de IU na amostra foi de 56,4\%. A IU de urgência associou-se com o GNP ( $p=0,022)$. Todas as variáveis do esquema PERFECT foram superiores entre as idosas do GP em relação ao GNP, com diferença significativa para a variável repetições $(p=0,008)$ e rapidez $(p=0,022)$. Na perineometria, as funções das fibras de contração rápida $(p=0,008)$ e das fibras de contração lenta $(p=0,05)$ foram superiores no GP. Conclusão: As idosas do GP apresentam melhor função muscular do assoalho pélvico. Entretanto, a prevalência de IU foi maior nesse grupo, sugerindo influência da variável idade no mecanismo de continência urinária.

Palavras-chave: assoalho pélvico; períneo; força muscular; incontinência urinária; atividade física; idoso.

Received: 07/28/2010 - Revised: 01/13/2011 - Accepted: 03/22/2011 


\section{Introduction $: \because$.}

During the aging process, the female lower urinary tract begins to show changes such as muscle atrophy due to estrogen deficiency ${ }^{1,2}$, replacement of muscle tissue by fat tissue ${ }^{3}$ and a consequent reduction in the contraction strength of pelvic floor muscles ${ }^{4}$, which may lead to involuntary urine loss.

According to the International Continence Society, urinary incontinence (UI) is defined as the complaint of any involuntary loss of urine. It can be classified as stress UI (SUI) when it is associated with increased intra-abdominal pressure, urge UI (UUI) when combined with a strong desire to urinate or mixed UI (MUI) when both types are present ${ }^{5}$. The prevalence of urinary incontinence increases with age, occurring in $26.6 \%$ of women aged 65 to 74 and in $41.8 \%$ of those over $75^{6}$.

Some strategies can minimize the effects of UI during the aging process. Physical activity acts positively on the continence mechanism because it helps maintain body weight and prevent obesity, since fat can cause chronic elevation of intraabdominal pressure and weaken pelvic support structures ${ }^{7,8}$. Ree, Nygaard and $\mathrm{B} \varnothing^{9}$ observed that strength training can increase the volume of the pelvic floor muscles, enabling contraction at certain times when there is increased intra-abdominal pressure.

However, some studies ${ }^{10,11}$ have demonstrated that physical activity in women is a risk factor for developing urinary incontinence, especially during effort, due to increased ground reaction force and, consequently, abdominal pressure, which influences pelvic floor muscles ${ }^{9}$. Jiang et al. ${ }^{12}$ claim that loss of functional continence mechanism (bladder support) is related to the frequency of physical exercise, especially high-impact exercise, which compromises pelvic floor support, suspension and restraint mechanisms by means of severe and repeated overload $^{13,14}$.

In this context, Borin ${ }^{15}$ evaluated the pelvic floor muscle pressure of female athletes and found that volleyball and basketball players had lower values than sedentary women. However, most studies ${ }^{15,16}$ that analyze groups of young athletes involved in high-impact physical activity do not associate their findings with the perineal function of moderately active and sedentary elderly women. In addition, the literature suggests that female gender and increasing age are important risk factors for $\mathrm{UI}^{17-19}$.

Given the demographic transition phenomenon referred to as the feminization of aging ${ }^{20}$, in which the proportion of women in the elderly population is higher than men, as well as the increased participation of women in physical activity programs ${ }^{21}$, research about the impact of such factors on this population is of increasing importance. Therefore, this study aims to identify the presence of UI and to compare the perineal muscle function of physically active and sedentary elderly women.

\section{Methods $: \because$.}

\section{Type of study and casuistry}

For this descriptive, cross-sectional study ${ }^{22}$, elderly female volunteers over 60 years of age were selected. The volunteers were divided into two groups: those involved in regular physical activity (AG) and those who were not (i.e., sedentary) (SG).

Each group had different inclusion criteria. AG ( $\mathrm{n}=28)$ consisted of elderly women who had been participating in physical activity projects sponsored by the Study Group on Advanced Age (GETI) of the Universidade do Estado de Santa Catarina (UDESC), Florianópolis, SC, Brazil and the Physical Activity for Seniors Group of the Centro Federal de Educação Tecnológica (CEFET) for at least six months. The SG $(n=11)$ consisted of elderly women who had not been involved in any form of regular physical exercise for at least six months and who participated in other types of GETI programs such as computer training and singing therapy.

Elderly women reporting damage to the lower urinary tract, pain when urinating or any other indication of urinary tract infection were excluded from the sample.

\section{Instruments and data collection}

First, both groups were evaluated using a semi-structured interview that included both open and multiple choice questions on risk factors for pelvic floor muscle weakening, which were divided into the following categories: gynecological, obstetrical, clinical, behavioral, hereditary and anthropometric. The presence of UI symptoms was also identified by the following question, which was posed in Huang et al. ${ }^{23}$ : "During the last year, did you lose urine (unintentionally in your underwear) at least once a month?"

The type of UI was identified by means of two questions: a) "Do you lose urine when coughing, sneezing, pushing or carrying weight?" (a positive response indicated SUI); b) "Do you lose urine before you get to the bathroom after either feeling a strong urge to urinate or without notice?" (a positive response indicated UUI). When both types were present, the case was considered MUI.

Following studies by $\mathrm{MazO}^{24}$ and Benedetti, Mazo and Barros ${ }^{25}$, categorization of the elderly women into physically active and sedentary groups was carried out by applying the "Recreational Physical Activity, Sport, Exercise and Leisure" section of the International Physical Activity Questionnaire adapted for the 
elderly. Women engaged in moderate and/or vigorous physical activity for 150 minutes or more per week were considered active (AG), while women engaged in zero minutes per week of such activity were considered sedentary (SG).

A Plenna digital scale (Wind MEA 07710) was used to determine body mass, and height was measured with a WCS $217 \mathrm{~cm}$ stadiometer. To measure the circumference of the last rib and iliac crest, an ISP brand tape measure was used.

For the physical examination, the participant lay on a stretcher in the supine position with her head on a pillow, her hips flexed and slightly abducted, her knees flexed and her feet flat on the stretcher. The following points were evaluated in the exam, as recommended by Chiarapa, Cacho and Alves ${ }^{14}$ and Moreno $^{26}$ : the tone of the fibrous center of the perineum, anovulvar distance, awareness of pelvic floor muscle contraction and the usage of adductors and gluteus muscles as well as the influence of the lumbosacral joint during this contraction.

While still in this position but having the knees supported with an approximately $20 \mathrm{~cm}$ high wedge, a vaginal examination was performed to check for symmetry of the pelvic floor beams and for the presence of prolapse during the Valsalva maneuver. Subsequently, the subjective muscle function of the pelvic floor was evaluated using the PERFECT scheme, which was developed by $\mathrm{B} \varnothing$ and Larsen ${ }^{27}$ and whose objective is to quantify the intensity, duration and support of perineal muscle contraction (Appendix 1).

To objectively measure perineal muscle function, a Perina $\left(\mathrm{QUARK}^{\circledR}\right)$ perineometer was used. This device uses pressure electromyography to record the action potentials of pelvic floor muscle contractions and translates their intensity into visual signals. It uses an inflatable vaginal probe as a sensor and measures perineal muscle function by pressure activation of the pelvic floor muscles during contraction. The equipment's unit of measure is $\mathrm{cm}_{2} \mathrm{O}$.

The participant remained in the same position during this step as in the vaginal exam. The vaginal probe, protected with a non-lubricated condom, was introduced into the vaginal canal of the participant. After introduction, the insufflator was slowly pressed once until slight resistance was felt. This standard was adopted since no studies describing optimal insufflator pressure could be found in the literature. The central part of the probe was insufflated in this procedure. To correctly determine the perineal muscle contraction pressure, the volunteer was told to relax and, before beginning the contraction, the perineometer was reset so that the central part of the probe could be accommodated to vaginal tone.

Five fast ( $1 \mathrm{~s}$ ) perineal contractions were performed with a $5 \mathrm{~s}$ interval between each contraction. Five slow perineal contractions were then performed according to the item "Repetitions" in the PERFECT scheme. The same rest interval was used between slow contractions. All contraction values were recorded.

The perineal contractions were performed during expiration and the participants were instructed about correct contraction of the pelvic floor muscles without using the adductors and gluteus muscles. The use of the wedge for knee support also minimized this problem. A single researcher interviewed and evaluated all the participants.

\section{Data treatment}

Data were stored in Microsoft Excel ${ }^{\circledR}$ and each participant was registered under a coded number. Statistical analysis was performed using the Statistical Package for Social Sciences (SPSS) v17.0.

Initially, all variables were descriptively analyzed using simple frequency and percentages (categorical variables) and measures of position and dispersion (numerical variables). For association between categorical variables, the chi-square $\left(\chi^{2}\right)$ test was used, or Fisher's Exact test when necessary. The Mann-Whitney test was used to compare numerical variables between groups. The significance level was set at 5\%.

\section{Ethical procedures}

This study fulfilled the requirements of resolution 196/96 of the National Health Council of Brazil and was approved by the UDESC Ethics Committee on Human Research under protocol 03/2010.

Upon agreeing to participate in the study, each elderly volunteer signed two copies of an informed consent form, with one copy remaining in the volunteer's possession and the other in the researcher's.

\section{Results $\because \because$.}

The study sample consisted of 39 elderly women (aged 60 or older): eleven were sedentary (SG) and 28 were physically active (AG). The physical exercise programs in which the AG participated included: cardio-strength training (23; 85.7\%), swimming $(02 ; 10.7 \%)$, dance $(02 ; 10.7 \%)$ and strength training $(01 ; 2.6 \%)$.

Regarding sociodemographic data, most of the elderly women in this study were either married $(22 ; 56.4 \%)$ or widows (13; 33.7\%), completed high school $(13 ; 33.7 \%)$ or did not complete middle school $(11 ; 28.2 \%)$ and were currently retired $(21 ; 53.8 \%)$.

Table 1 compares risk factors and pelvic floor muscle weakening between AG and SG. The groups shared similar 
characteristics except for age $(p=0.040)$, which was higher in AG. Among anthropometric factors, AG had a higher mean body mass index (BMI) and waist circumference (WC), although not significantly so ( $\mathrm{p}=0.158$ and $\mathrm{p}=0.149$, respectively).

Regarding the association between UI symptoms and physical activity (Table 2), 56.4\% of the volunteers complained of incontinence, with SUI being the most common type (51.3\%). The presence of UUI was reported by $28.2 \%$ of the sample and was significantly associated with both AG and SG $\left(\chi^{2}=5.25 ; p=0.022\right)$, having a greater tendency in SG (54.5\%) (residual adjustment $\geq 2.0$ ). Although the presence of MUI was not significant in either group, SG (55.6\%) had a higher tendency toward this type of urinary loss. Furthermore, only one AG volunteer reported urine loss during physical exercise.

Regarding the physical examination, no association was observed between categorical variables and the AG and SG groups. However, the high frequency of bladder prolapse $(82.4 \%)$ and awareness of pelvic floor muscle contraction (78.1\%) among women in the AG (Table 3) stand out among the results. Regarding the PERFECT scheme (Strength, Endurance, Repetition, Speed), higher medians for all variables were found in AG, suggesting that pelvic floor function was better

Table 1. Comparison of risk factors to the weakening of the pelvic floor muscles in women older practitioners (AG) and non-practitioners (SG) of physical activity.

\begin{tabular}{|c|c|c|c|}
\hline Variable & $A G(n=28)$ & $S G(n=11)$ & $p$ \\
\hline$A g e_{\text {(mean } \pm S D \text { years) }}$ & $68.14 \pm 5.1$ & $64.82 \pm 4.2$ & $0.04^{*}$ \\
\hline \multicolumn{4}{|l|}{ Gynecological factors } \\
\hline Time of menopause ${ }_{\text {(mean } \pm S D \text { years) }}$ & $19.68 \pm 7.5$ & $16.91 \pm 7.0$ & 0.221 \\
\hline Hormone replacement therapy (Yes: $f(\%))$ & $2(66.7)$ & $1(33.7)$ & 0.248 \\
\hline Surgical procedures $_{(\text {Yes: } f(\%))}$ & $14(63.6)$ & $8(36.4)$ & 0.977 \\
\hline Access surgery & $8(66.7)$ & $4(33.3)$ & 0.795 \\
\hline \multicolumn{4}{|l|}{ Obstetric factors } \\
\hline Three or more pregnancies & $23(74.2)$ & $8(25.8)$ & 0.532 \\
\hline Three or more deliveries $_{(f(\%))}$ & $20(76.9)$ & $6(23.1)$ & 0.557 \\
\hline Three or more normal deliveries ${ }_{(\dagger(\%))}$ & $16(72.7)$ & $6(27.3)$ & 0.760 \\
\hline Realization of episiotomy & $17(77.3)$ & $5(22.7)$ & 0.642 \\
\hline Occurrence of laceration (Yes: $f(\%))$ & $2(66.6)$ & $1(33.3)$ & 0.248 \\
\hline Use of forceps ${ }_{(\text {Yes: } f(\%))}$ & $2(50.0)$ & $2(50.0)$ & 0.203 \\
\hline Greater weight born ${ }_{(\text {mean } \pm S D ~ K g)}$ & $3.58 \pm 0.54$ & $2.95 \pm 1.55$ & 0.379 \\
\hline \multicolumn{4}{|l|}{ Behavioral factors } \\
\hline Smoking $_{(\text {Yes: } f(\%))}$ & $0(0.0)$ & $0(0.0)$ & -- \\
\hline Weight change $_{(\text {Yes: } f(\%))}$ & $18(72.0)$ & $7(28.0)$ & 0.712 \\
\hline Presence of constipation & $10(58.8)$ & $7(41.2)$ & 0.745 \\
\hline \multicolumn{4}{|l|}{ Hereditary factors } \\
\hline Race $_{(\text {Caucasian: }:(f(\%))}$ & $25(71.4)$ & $10(28.6)$ & 0.548 \\
\hline Family history of UI & $7(46.7)$ & $8(53.3)$ & 0.564 \\
\hline \multicolumn{4}{|l|}{ Anthropometric factors } \\
\hline Body mass index $_{(\text {mean } \pm S D ~ k g / m 2)}$ & $28.61 \pm 5.3$ & $26.16 \pm 3.0$ & 0.158 \\
\hline Waist circumference ${ }_{(\text {mean } \pm S D ~ c m)}$ & $93.38 \pm 13.8$ & $86.26 \pm 3.5$ & 0.149 \\
\hline
\end{tabular}

$p=s$ ignificance level of Mann-Whitney test for continuous variables and test of difference between two proportions for categorical variables. ${ }^{\dagger}$ Body mass index $\left(\mathrm{kg} / \mathrm{m}^{2}\right)=$ Body Mass $(\mathrm{kg})$ / Height $(\mathrm{m})^{2}$; ${ }^{\ddagger}$ Waist circumference $(\mathrm{cm})=$ Circumference Last Rib (cm) / Circumference lliac Crest (cm); ${ }^{p} \leq 0.05$.

Table 2. Association between symptoms of Urinary Incontinence (UI) and the groups of elderly women practitioners (AG) and non-practitioners (SG) of physical activity.

\begin{tabular}{|c|c|c|c|c|c|}
\hline Variable & $\begin{array}{c}A G(n=28) \\
f(\%)\end{array}$ & $\begin{array}{c}S G(n=11) \\
f(\%)\end{array}$ & $\begin{array}{c}\text { Total }(n=39) \\
f(\%)\end{array}$ & $\chi^{2}$ & $p$ \\
\hline Presence of UI & $14(63.6 \%)$ & $8(36.4 \%)$ & $22(56.4 \%)$ & 1.66 & 0.288 \\
\hline Presence of SUI & $13(65.0 \%)$ & $7(35.0 \%)$ & $20(51.3 \%)$ & 0.93 & 0.333 \\
\hline Presence of UUI & $5(45.5 \%)$ & $6^{*}(54.5 \%)$ & $11(28.2 \%)$ & 5.25 & $0.022^{*}$ \\
\hline Presence of MUI & $4(44.4 \%)$ & $5^{\star}(55.6 \%)$ & $9(23.1 \%)$ & 4.32 & 0.085 \\
\hline
\end{tabular}

SUI=Stress Urinary Incontinence; UUI=Urge Urinary Incontinence; MUI=Mixed Urinary Incontinence; $\chi^{2}=$ Chi-Square test; $p=$ level of significance; ${ }^{*}$ Residual Adjustment $\geq 2.0 ;$ * $p \leq 0.05$. 
in this group. Repetition of sustained contractions (Repetitions) and fast contractions (Speed) was significantly different between $A G$ and $S G(U=70.0 ; p=0.008$ and $U=81.0 ; p=0.022$, respectively).

The perineometry results indicated that AG fast-twitch fiber function was significantly higher than SG, with medians of 22 and 6.5, respectively ( $U=70.5 ; p=0.008)$. This was also true for slow-twitch fiber function, with a median of 10 in the AG and 2 in the SG (U=91.0; $\mathrm{p}=0.050)$.

\section{Discussion $\because:$.}

The age factor, especially in women, tends to be an important cause of urinary problems and involves changes such as a decrease in collagen fibers ${ }^{3}$, decreased bladder storage capacity and low post-menopause levels of estrogen ${ }^{29}$. The patient's obstetric and gynecological history can also contribute to the weakening of these muscles ${ }^{30}$. The occurrence of UI in this study was higher (56.4\%) than the values found in a recent study by Smith et al. ${ }^{31}$, where the prevalence was $29.5 \%$ among women aged 60 or older. The high prevalence of UI found in this study could be due to the fact that most of the women interested in participating had a prior urinary incontinence problem and thus were concerned about pelvic floor muscle function. This kind of bias can occur in studies whose sample consists of volunteers. However, when dealing with an elderly population, there are few alternatives when developing a study involving a gynecological examination.

Regarding the types of urinary incontinence, most elderly women reported SUI (50.1\%), while $28.2 \%$ had UUI and $23.1 \%$ MUI. Barros, Lucena and Anselmo ${ }^{1}$ and Mourão et al. ${ }^{3}$ explain that the female lower urinary tract shows changes due to estrogen deficiency such as decreased pelvic floor muscle contraction force, which can cause involuntary loss of urine during effort. Furthermore, structural changes to the detrusor muscle

Table 3. Comparison and association between the items of physical examination of the pelvic floor and groups of elderly women practitioners (AG) and non-practitioners (SG) of physical activity.

\begin{tabular}{|c|c|c|c|c|c|}
\hline $\begin{array}{l}\text { Variable } \\
\text { Categorical }\end{array}$ & $\begin{array}{c}A G(n=28) \\
f(\%)\end{array}$ & $\begin{array}{c}S G(n=11) \\
f(\%)\end{array}$ & $\begin{array}{c}\text { Total }(n=39) \\
f(\%)\end{array}$ & $\chi^{2}$ & $p$ \\
\hline \multicolumn{6}{|l|}{ Distance anu-vulvar } \\
\hline Larger than $3 \mathrm{~cm}$ & $10(76.9)$ & $3(23.1)$ & $13(33.3)$ & \multirow{2}{*}{0.253} & \multirow{2}{*}{0.615} \\
\hline Smaller than $3 \mathrm{~cm}$ & $18(69.2)$ & $8(30.8)$ & $26(66.7)$ & & \\
\hline \multicolumn{6}{|l|}{ Tonicity of FCTP } \\
\hline Normal & $24(75.0)$ & $8(25.0)$ & $32(82.1)$ & \multirow{2}{*}{0.904} & \multirow{2}{*}{0.379} \\
\hline Altered & $4(57.1)$ & $3(42.9)$ & $7(17.9)$ & & \\
\hline \multicolumn{6}{|c|}{ Awareness of the contraction } \\
\hline Aware & $25(78.1)$ & $7(21.9)$ & $32(82.1)$ & \multirow{2}{*}{3.528} & \multirow{2}{*}{0.083} \\
\hline Not aware & $3(42.9)$ & $4(57.1)$ & $7(17.9)$ & & \\
\hline \multicolumn{6}{|l|}{ Use muscle parasite } \\
\hline Yes & $18(72.0)$ & $7(28.0)$ & $25(64.1)$ & \multirow{2}{*}{0.001} & \multirow{2}{*}{1.000} \\
\hline Not & $10(71.4)$ & $4(57.1)$ & $14(35.9)$ & & \\
\hline \multicolumn{6}{|l|}{ Use joint of lumbosacral } \\
\hline Yes & $4(66.7)$ & $2(33.3)$ & $6(15.4)$ & \multirow{2}{*}{0.092} & \multirow{2}{*}{1.000} \\
\hline Not & $24(72.7)$ & $9(27.3)$ & $33(84.6)$ & & \\
\hline \multicolumn{6}{|c|}{ Bilateral symmetry of the beams } \\
\hline Yes & $24(77.4)$ & $7(22.6)$ & $31(79.5)$ & \multirow{2}{*}{2.361} & \multirow{2}{*}{0.188} \\
\hline Not & $4(50.0)$ & $4(50.0)$ & $8(20.5)$ & & \\
\hline \multicolumn{6}{|c|}{ Presence of bladder prolapse } \\
\hline Yes & $14(82.4)$ & $3(17.6)$ & $17(43.6)$ & \multirow{2}{*}{1.659} & \multirow{2}{*}{0.288} \\
\hline Not & $14(63.6)$ & $8(36.4)$ & $22(56.4)$ & & \\
\hline Ordinal & $\mathrm{Md}$ & Md & $\mathrm{Md}$ & U & $p$ \\
\hline \multicolumn{6}{|l|}{ PERFECT scheme } \\
\hline Power & 4.0 & 3.0 & 3.0 & 96.0 & 0.072 \\
\hline Endurance & 5.5 & 4.0 & 5.0 & 116.5 & 0.246 \\
\hline Repeticions & 5.0 & 2.0 & 5.0 & 70.0 & $0.008^{*}$ \\
\hline Fast & 10.0 & 5.0 & 10.0 & 81.0 & $0.022^{*}$ \\
\hline \multicolumn{6}{|l|}{ Perineometry } \\
\hline Fast fibers & 22.0 & 6.5 & 16.0 & 70.5 & $0.008^{*}$ \\
\hline Slow fibers & 10.0 & 2.0 & 8.0 & 91.0 & $0.050^{*}$ \\
\hline
\end{tabular}

FCTP=Fibrous of the central tendon of the perineum; $\chi^{2}=$ Chi-Square test; $U=$ test $U$ of Mann-Whitney; Md=Median; $p=$ level of significance; ${ }^{*} p<0.05$. 
that occur during the aging process, such as the development of fibrosis and hypersensitivity to norepinephrine, result in reduced bladder capacity and involuntary contractions ${ }^{32}$, which cause urinary urgency symptoms and/or UUI.

Regarding physical activity, the results indicated that AG had a higher incidence of urinary incontinence (63.6\%), which does not agree with the literature. Smith et al. ${ }^{31}$ found an association between physical exercise and lower UI rates and encouraged moderate-intensity exercise in order to promote urinary continence. Kikuchi et al. ${ }^{33}$ found that, compared to those with low physical activity levels, older adults with high physical activity levels had a lower prevalence of UI, which indicates that physical exercise can prevent the occurrence of urinary incontinence.

Regarding the type of UI, SG showed a tendency towards urgency symptoms $(p=0.022)$. In a cross-sectional study, Song et $a l .^{34}$ observed that women who exercised at least once a week were less likely to have UUI. Townsend et al. ${ }^{7}$ also found lower rates of UUI in women with higher levels of physical activity (OR=0.53; 95\% CI=0.31 - 0.90). These results demonstrate that urinary urgency symptoms may also be reduced by regular physical exercise.

Regarding urine loss during exercise, only one volunteer registered such a complaint. Nygaard et al. ${ }^{35}$ and $B ø^{13}$ claim that professional sports is an additional risk for developing UI, especially when high-impact activities are involved. It is believed that the recreational nature of the senior cardiovascular workout, in which the majority $(85.7 \%)$ participated, may explain the low incidence of urinary incontinence during physical exercise.

Bernardes et al. ${ }^{36}$ indicate that a pelvic floor with deficient or inadequate muscle function is an important etiological factor in UI. According to Bø and Sherburn ${ }^{37}$, pelvic floor muscle function is defined as the ability to perform a correct contraction, i.e., tightening around the pelvic opening and moving the pelvic floor internally. As shown in this study, physical activity appears to contribute to better perineal function among elderly women. $\mathrm{B} \emptyset^{13}$ suggests that a reflex contraction of the pelvic floor muscles occurs simultaneously with an increase in abdominal pressure during exercise. Ree, Nygaard and $B \varnothing^{9}$ affirm that physical exercise can increase the volume of the pelvic floor muscles, making them capable of contracting during increased intra-abdominal pressure.

A study by Stach-Lempinen et al. ${ }^{38}$ evaluated 82 women with UI using the Oxford scale, which is a subjective measure of perineal contractility. The authors found an association between physical activity level and pelvic muscle contraction, with $43.5 \%$ of the more active women reaching a good contraction level, compared to $27 \%$ among the less active. In the present study, all variables related to perineal contraction functionality were also higher among active elderly women. Moreover, a classic study by $\mathrm{B} ø$ and Finckenhagen ${ }^{39}$ pointed out that the maximum average power of perineal contraction among healthy women was $19.7 \pm 3.2 \mathrm{~cm} \mathrm{H}_{2} \mathrm{O}$. This value is similar to that found during fast fiber measurement in AG ( $\mathrm{Md}=22.0 \mathrm{~cm} \mathrm{H}_{2} \mathrm{O}$ ).

Furthermore, with regard to perineal muscle function, it was observed that the slow fiber-related variables in both the PERFECT scheme (Endurance and Repetitions) and in perineometry had lower medians than fast fiber-related variables in both groups. According to Danforth et al..$^{40}$, advancing age determines the natural aging of muscle fibers, including hypotrophy or replacement with adipocytes, which can effectively contribute to weakness in the pelvic floor and the UI process.

As noted in this study, the occurrence of UI, even with an intact pelvic floor, is commonly observed in clinical practice. Souza et al. $^{41}$ recommend caution about exclusively attributing UI etiology to inappropriate urethral support or atrophy of pelvic floor muscles. In this context, Figueiredo et al. ${ }^{42}$ report that women with the same degree of perineal muscle function may report different UI symptoms. Thus, it is important to consider that there are multiple risk factors associated with the failure of pelvic floor muscles ${ }^{41}$.

Considering the above-mentioned observations, the high prevalence of urinary incontinence in AG could be seen as a product of age and the higher mean anthropometric variables in this group. According to Delancey ${ }^{43}$, maximum urethral closure pressure and periurethral fiber quantities decrease with advancing age. Townsend et al. ${ }^{44}$ and Krause et al. ${ }^{45}$ have observed that high BMI and waist circumference increase the risk of developing SUI due to increased intra-abdominal pressure and other effects on urethral structures. Thus, centrally distributed adipose tissue can cause a chronic elevation in intraabdominal pressure and, consequently, in intravesical pressure, which leads to tension in the urethral support structures and increased risk of SUI, even when there is full muscle function of pelvic floor ${ }^{45}$.

The results indicate that physically active elderly women show better pelvic floor muscle function than their sedentary counterparts. Thus, encouraging physical activity for the elderly population is important since, in addition to its other benefits, it also improves pelvic floor functionality. Physical activity can also collaborate substantially to weight control, which is UI risk factor ${ }^{46}$. The results also suggest that specific pelvic floor contraction exercises should be incorporated into physical activity routines because they lead to improved automatic contractions in the pelvic floor during times of increased intra-abdominal pressure. 
Both the small sample and the difference in group size can be considered study limitations. Nevertheless, this research is of great importance since pelvic floor functionality has been studied at a national level only in young, physically active women and has been neglected in the elderly female population, which is constantly growing.

We suggest that future studies invest in controlling the sample size for more homogeneous groups and involve a blinded evaluator. Greater control of the type of physical activity in which the volunteers participate may also be useful, as well as assessing the time that volunteers have participated (AG) or not participated in these activities (SG). Moreover, other anthropometric measurement methods such as skinfolds and bioelectrical impedance can be included. Other risk factors could also be controlled, since many of them are involved in pelvic floor weakening and UI symptoms in elderly women.

\section{References $: \because$ 。}

1. Barros JD, Lucena ACT, Anselmo CWSF. Incontinência urinária de esforço em atletas do sexo feminino: uma revisão da literatura. An Fac Med Univ Fed Pernamb. 2007;52(2):173-80.

2. Ramos JGL, Schmidt AP, Martins-Costa SH. Anormalidade da estática pélvica. In: Freitas F, Menke CH, Rivoire WA, Passos EP. Rotinas em ginecologia. $5^{a}$ ed. Porto Alegre: Artmed; 2006.

3. Mourão FAG, Lopes LN, Vasconcellos NPC, Almeida MBA. Prevalência de queixas urinárias e 0 impacto destas na qualidade de vida de mulheres integrantes de grupos de atividade física. Acta Fisiátrica. 2008;15(3):170-5.

4. Pauls J. Incontinência urinária e comprometimento do assoalho pélvico no idoso. In: Guccione AA. Fisioterapia Geriátrica. Rio de Janeiro: Guanabara Koogan; 2002. p. 322-32.

5. Abrams P, Cardozo L, Fall M, Griffiths D, Rosier P, Ulmsten U, et al. The standardization of terminology of lower urinary tract function: report from the standardization sub-committee of the international continence society. Neurourol Urodyn. 2002;21(2):167-78.

6. Espunã-Pons M, Guiteras PB, Sampere DC, Bustos AM, Penina AM. Prevalência de incontinência urinaria en Cataluña. Med Clin (Barc). 2009;133(18):702-5.

7. Townsend MK, Danforth KN, Rosner B, Curhan GC, Resnick NM, Grodstein F. Physical Activity and Incident Urinary Incontinence in Middle-Aged Women. J Urol. 2008;179(3):1012-7.

8. Danforth KN, Shah AD, Townsend MK, Lifford KL, Curhan GC, Resnick NM, et al. Physical Activity and Urinary Incontinence Among Healthy, Older Women. Obstet Gynecol. 2007;109(3):721-7.

9. Ree ML, Nygaard I, Bø K. Muscular fatigue in the pelvic floor muscles after strenuous physical activity. Acta Obstet Gynecol Scand. 2007;86(7):870-6.

10. Thyssen $H H$, Clevin L, Olesen S, Lose G. Urinary incontinence in elite female athletes and dancers. Int Urogynecol J Pelvic Floor Dysfunct. 2002;13(1):15-7.

11. BøK, Borgen JS. Prevalence of stress and urge urinary incontinence in elite athletes and controls. Med Sci Sports Exerc. 2001;33(11):1797-802.

12. Jiang K, Novi JM, Darnell S, Arya LA. Exercise and urinary incontinence in women. Obstet Gynecol Surv. 2004;59(10):717-21.

13. Bø K. Urinary incontinence, pelvic floor dysfunction, exercise and sport. Sports Med. 2004;34(7):451-64

14. Chiarapa TR, Cacho DP, Alves AFD. Avaliação Cinético Funcional. In: Chiarapa TR, Cacho DP, Alves AFD. Incontinência urinária feminina: assistência fisioterapêutica e multidisciplinar. São Paulo: Livraria Médica Paulista; 2007. p. 71-122.

15. Borin LCMS. Avaliação pressórica da musculatura do assoalho pélvico de mulheres jovens atletas [dissertação]. Piracicaba: Universidade Metodista de Piracicaba; 2006.

16. Larosa AV, Magnani PS. Comparação da funcionalidade do assoalho pélvico entre mulheres atletas e não-atletas [TCC]. Araraquara: Centro Universitário de Araraquara; 2005.

17. Alvaro R, Araco F, Gravante G, Sorge R, Overton J, Vellone E, et al. Epidemiological aspects of urinary incontinence in a female population of an Italian region. Int Urogynecol J Pelvic Floor Dysfunct. 2010;21(7):873-83

18. Yagmur $\mathrm{Y}$, Ulukoca N. Urinary incontinence in hospital-based nurses working in Turkey. Int $\mathrm{J}$ Gynaecol Obstet. 2010;108(3):224-7.

19. Onur R, Deveci SE, Rahman S, Sevindik F, Acik Y. Prevalence and risk factors of female urinary incontinence in eastern Turkey. Int J Urol. 2009;16(1):566-9.
20. Neri AL. Idosos no Brasil vivências, desafios e expectativas na terceira idade. Fundação Perseu Abramo; 2007.

21. Andreotti MC, Okuma SS. Perfil sócio demográfico e de adesão inicial de idosos ingressantes em um programa de educação física. Rev Paul Educ Fís São Paulo. 2003;17(2):142-53.

22. Gil AC. Como elaborar projetos de pesquisa. $4^{a}$ Ed. São Paulo: Atlas; 2009.

23. Huang AJ, Brown JS, Thom DH, Fink HA, Yaffe K. Urinary incontinence in older communitydwelling women: the role of cognitive and physical function decline. Obstet Gynecol 2007;109(4):909-16

24. Mazo GZ. Atividade física e qualidade de vida de mulheres idosas [tese]. Portugal: Faculdade de Ciências do Desporto e de Educação Física, Universidade do Porto; 2003.

25. Benedetti TB, Mazo GZ, Barros MVG. Aplicação do Questionário Internacional de Atividades Físicas para avaliação do nível de atividades físicas de mulheres idosas: validade concorrente e reprodutibilidade teste-reteste. Rev Bras Ciên Mov. 2004;12(1):25-34.

26. Moreno AL. Avaliação Fisioterapêutica. In: Moreno AL. Fisioterapia em Uroginecologia. São Paulo: Manole; 2004. p. 101-6.

27. Bø K, Larsen S. Pelvic floor muscle exercise for the treatment of female stress urinary incontinence. Classification and characterization of responders. Neurourol Urodyn. 1992;11(1):497-507

28. Ortiz OC, Nuoez FC, Gutnisky R, Cortece G. Valoración dinâmica de la disfuncion perineal em la mujer. Propuesta de classificación. Obstet Ginec Lat Americ. 1994;52(1):92-8.

29. Higa R, Lopes MHBM, Reis MJ. Fatores de risco para incontinência urinária na mulher. Rev Esc Enferm USP. 2008;42(1):187-92.

30. Moller LA, Lose G, Jorgensen T. Risk factors for lower urinary tract symptoms in women 40 to 60 years of age. Obstet Gynecol. 2000;96(3):446-51.

31. Smith AL, Wang PC, Anger JT, Mangione CM, Trejo L, Rodrigues LV, et al. Correlates of urinary incontinence in community-dwelling older latinos. J Am Geriatr Soc. 2010;58(6):1170-6.

32. Siroky MB. The aging bladder. Rev Urol. 2004;6 Suppl 1:S3-7

33. Kikuchi A, Niu K, Ikeda Y, Hozawa A, Nakagawa H, Guo H, et al. Association between physical activity and urinary incontinence in a community-based elderly population aged 70 years and over. Eur Urol. 2007;52(3):868-74.

34. Song YF, Zhang WJ, Song J, Xu B. Prevalence and risk factors of urinary incontinence in Fuzhou Chinese women. Chin Med J. 2005;118(11):887-92.

35. Nygaard IE, Thompson FL, Svengalis SL, Albright JP. Urinary incontinence in elite nulliparous athletes. Obstet Gynecol. 1994;84(2):183-7.

36. Bernardes NO, Péres FR, Souza ELBL, Souza OL. Métodos de tratamento utilizados na incontinência urinária de esforço genuína: um estudo comparativo entre cinesioterapia e eletroestimulação endovaginal. Rev Bras Ginecol Obstet. 2000;22(1):49-54.

37. Bø K, Sherburn M. Evaluation of female pelvic-floor muscle function and strength. Phys Ther 2005;85(3):269-82

38. Stach-Lempinen B, Nygard C, Laippala P, Metsanoja R, Kujansuu E. Is physical activity influenced by urinary incontinence? BJOG. 2004;111(5):475-80.

39. Bø K, Finckenhagen HB. Vaginal palpation of pelvic floor muscle strength: inter-tes 
reproducibility and the comparison between palpation and vaginal squeeze pressure. Acta Obstet Gynecol Scand. 2001;80(10):883-7.

40. Danforth KN, Townsend MK, Lifford K, Curhan GC, Resnick NM, Grodsten F. Risck factors for urinary incontinence among middle-aged women. Am J Obstet Gyneco. 2006;194(2):339-45

41. Souza CEC, Lima RM, Bezerra LMA, Pereira RW, Moura TK, Oliveira RJ. Estudo comparativo da função do assoalho pélvico em mulheres continentes e incontinentes após a menopausa. Rev Bras Fisioter. 2009;13(6):535-1.

42. Figueiredo EM, Lara J0, Cruz MC, Quintão DMG, Monteiro MVC. Perfil sociodemográfico e clínico de usuárias de serviço de fisioterapia uroginecológica da rede pública. Rev Bras Fisioter.
2008;12(2):136-42.

43. Delancey J0. Why do women have stress urinary incontinence. Neurourol Urodyn. 2010;29 Suppl 1:S13-7.

44. Townsend MK, Curhan GC, Resnick NM, Grodstein F. BMI, waist circumference, and incident urinary incontinence in older women. Obesity. 2008;16(4):881-6.

45. Krause MP, Albert SM, Elsangedy HM, Krinski K, Goss FL, da Silva SG. Urinary incontinence and waist circumference in older women. Age Ageing. 2010;39(1):69-73.

46. Goode PS, Burgio KL, Richter HE, Markland AD. Incontinence in older women. JAMA 2010;303(21):2172-81.

Appendix 1. Scheme PERFECT subjective functional evaluation of the pelvic floor adapted.

\begin{tabular}{|c|c|c|}
\hline \multicolumn{3}{|c|}{ Subjective Evaluation of Muscle Contraction Perineal - Scheme PERFECT } \\
\hline$P$ & Power* & $\begin{array}{l}\text { Muscle strength: assessing the presence and intensity of voluntary muscle contraction, according to Ortiz et al. }{ }^{25} \text {. } \\
\text { Grade 0: No perineal function objectively, even palpation. } \\
\text { Grade 1: Function perineal objective absent, contraction recognizable only by palpation. } \\
\text { Grade 2: Function perineal objectively weak, contraction recognizable by palpation. } \\
\text { Grade 3: Function perineal this objective opposition and resistance not kept longer than five seconds to palpation. } \\
\text { Grade 4: Function perineal this objective opposition and resistance held more than five seconds on touch. }\end{array}$ \\
\hline $\mathrm{E}$ & Endurance & $\begin{array}{l}\text { Maintenance of contraction: is the time, in seconds, with voluntary contraction maintained and sustained as a result of } \\
\text { slow muscle fibers. Join the time reached (maximum ten seconds). }\end{array}$ \\
\hline $\mathrm{R}$ & Repetitions & $\begin{array}{l}\text { Repeat the contractions kept: they correspond to the number of contractions with satisfactory supports (five seconds), } \\
\text { which can be performed after a rest period of four seconds between them. The number achieved without compromising } \\
\text { the intensity is recorded (maximum of ten repetitions). }\end{array}$ \\
\hline $\mathrm{F}$ & Fast & $\begin{array}{l}\text { Number of fast-twitch: corresponds to measure contractility of fast muscle fibers determined after two minutes of rest. It is } \\
\text { noted the number of rapid contractions of a second without compromising intensity (maximum ten times). }\end{array}$ \\
\hline $\mathrm{E}$ & Every & \\
\hline$\frac{C}{T}$ & Contraction & Monitoring progress through the timing of contractions. \\
\hline $\mathrm{T}$ & Timed & \\
\hline
\end{tabular}

* Originally, second Bø and Larsen ${ }^{26}$, the power is measured using the Oxford system. However, we chose to use the scale proposed by Ortiz et al. ${ }^{25}$. 